\title{
Computer-Aided-Instruction (CAI) as an Innovative Method for Optimizing the Quality of Social Studies Lecturers in Nigerian Tertiary Institutions for Quality Teacher Education in Nigeria
}

\author{
Mezieobi, Daniel Ibeawuchi ${ }^{1}$, Onyeanusi, Obiageli C. ${ }^{1}$, Chukwu, Peter N. ${ }^{1}$, \& Chukwu, Chineyere Loveth ${ }^{1}$ \\ ${ }^{1}$ Department Of Social Science Education, University Of Nigeria, Nsukka \\ Correspondence: Chukwu, Chineyere Loveth, Department Of Social Science Education, University Of Nigeria, Nsukka.
}

Received: November 4, 2018

Accepted: February 11, 2019 Online Published: April 27, 2019

doi:10.5539/res.v11n2p41

URL: https://doi.org/10.5539/res.v11n2p41

\begin{abstract}
This study focused on Computer-Aided-Instruction (CAI) as an innovative method for optimizing the quality of Social Studies lecturers in Nigerian tertiary institutions for quality teacher education in Nigeria. To achieve the purpose of this study, three research questions were posed to guide the study. The study adopted descriptive survey research design. The population of the study consisted of all the one hundred and sixty-two (162) Social studies education lecturers in public universities and colleges of education in South-East, Nigeria. A sample of 108 social studies lecturers was drawn for the study, using cluster sampling technique. Relevant data for the study were collected using a "Questionnaire on Effectiveness of CAI in Optimizing the Quality of Social Studies Lecturers in Nigerian Tertiary Institutions". Data collected were analysed using mean and standard deviation. The findings of the study indicated that: many social studies lecturers are not acquainted with the requisite knowledge and skills for teaching social studies; a good number of social studies lecturers are not acquainted with CAI as an innovative trend for accessing information; and that CAI helps in optimizing the quality of social studies lecturers in Nigerian tertiary institutions. Following the findings of this study, conclusion was drawn and recommendations were made to include that professionally qualified social studies lecturers should be recruited to teach social studies in Nigerian tertiary institutions, social studies lecturers ought to update their computer competences among others.
\end{abstract}

Keywords: computer-aided instruction, innovative method, quality of social studies lecturers, Nigerian tertiary institutions, quality teacher education

\section{Introduction}

Social studies is an educational discipline that is highly relevant to social, political, cultural, economic and technological development of a nation (Mezieobi, Ossai, Onyeanusi \& Egharevba, 2012). It is value-ladened (Nwaubani, 2010). Its contents are organized around social and environmental issues affecting man's existence and his capacity to manage and preserve the environment for sustainable development (Mezieobi, Akpochafo \& Mezieobi, 2010). Social studies teachers are the instruments used for the acquisition of the knowledge, attitudes and skills needed for national development. Following the inevitability of social studies in nation building and national development in Nigeria, it is quite imperative that social studies lecturers are acquainted with adequate knowledge, skills and pedagogies for teaching social studies through the use of Computer Assisted Instruction (CAI) which is an innovative method for boosting the effectiveness and quality of social studies lecturers for effective teacher education in Nigerian tertiary institutions.

Computer Assisted Instruction (CAI) is an innovative method of instruction that encourages interaction and instruction between the computer and a learner. It is an electronic education whereby the learner is in a friendly learning interaction with the computer which presents the programmed learning activity. Impliedly, computer plays the teacher role as it provides and imparts knowledge and skills to the learners. Mezieobi, Fubara and Mezieobi (2008:109) opined that "CAI is a functional instructional computer... in which there is a learning interaction between the instructional computers and students in favour of the learners". Similarly, Nwosu (2002) asserted that CAI is an automated instructional technique in which a computer is used to present an instructional programme to the learner through an interactive process. Its functions as Nwosu further maintained include presentation of materials or problem situation, guiding students' thinking, responding to students' questions, assessing students' performances, managing students' path through a course by selecting materials to be presented and assigning tasks to be performed or any combination of the functions. 
Education is the channel through which different societies develop and shape their members for societal continuity. Social studies teachers are inevitable educational tool for performing this task. Hence, the provision of quality teachers in all spheres of education is quite paramount for effective training of the learners and for societal advancement. Okolo and Nweze (2010) maintained that the main function of a teacher is to transmit knowledge, values and skills to the learners to move the society forward. In collaboration, Odigwe (2007) reiterated "teachers are at the center of the education system".

However, it is obvious that quality social studies teachers produce quality learners that are fully packaged for individual and societal advancement. Evidently, in Nigeria today many lecturers are not adequately acquainted with the requisite knowledge, skills and competencies that are germane for effective training of the learners. Social studies lecturers consequently are not exception. Many social studies lecturers are not adequately abreast with the basic facts, knowledge and skills for teaching social studies. Most of them do not acquaint themselves with the right pedagogies for teaching social studies. Hence, Mezieobi (2013) observed:

Most teachers of social studies in the teacher training institutions (Colleges of Education, a few institutes and faculties of Education in universities offering social studies programmes) have no professional training in the ontological, epistemological and axiological orientations of social studies. They are not themselves trained in social studies education... hence; the quality of social studies teachers in our school today is too poor. Pp 85, $162 \& 172$.

This has consequently led to the production of many half baked social studies graduates and has invariably marred the actualization of social studies objectives in tertiary institutions as Mezieobi (2013) further maintained that the poor quality of social studies teachers in the teacher training institutions has a deleterious spillover effect on their products who cannot perform implementation-wise more than their poor quality social studies teachers had exposed them to. Succinctly, Federal Republic of Nigeria in (2004) National Policy on Education stipulated that the quality of effective teaching is dependent on the capability of trained social studies teachers and ability to stimulate learning to an appreciable extent. Similarly, Enem (2005) observed that integrated social studies curriculum in Nigerian schools suffers instructional neglect which is largely attributed to teachers' inabilities to come to grip with the peculiar pedagogical demands of social studies. This has perturbed effective learning of social studies in schools. Invariably, there is need for optimization of the quality of social studies lecturers in Nigerian tertiary institutions.

CAI as an innovative strategy has the potential for increasing the quality of social studies lecturers in schools and consequently helps to increase access to and improvement of the relevance and quality of education. It greatly facilitates the acquisition and absorption of knowledge, skills and capabilities for effective teaching and more so paves way for accessing remote learning resources for more knowledge acquisition. CAI however is quite germane for the optimization of the quality of social studies lecturers in Nigerian Universities and Colleges of Education. It is of high relevance for this task since its use helps to equip social studies lecturers with the requisite trend of knowledge, skills and capabilities for learning maximization hence catalyzing the paradigmatic shift in both content and pedagogy that is at the heart of education reform in the 21 st century. Since social studies is societal and contemporary focused in its content, method, philosophy and nature, it is pertinent that the quality of its lecturers is optimized and boosted using CAI for enhancement of learning and effective achievement of social studies objectives at the tertiary level of Education. This paper therefore tends to determine the relevance of Computer Assisted Instruction (CAI) in the optimization of the quality of social studies lecturers in Nigerian tertiary institutions.

This study is anchored on Diffusion theory (Rogers 1962 in Okpeobo, 2018) which upholds that ideas, products, methods, information and facts speedily overtime gain momentum spread into a social structure or social system through some channels. The adoption of innovation is not simultaneous or automatic. There are early adoptors, and those who will adopt to changes later, including the conservatives who are resistant to change. Smith (2009) advanced that innovation requires creation of awareness of the need for innovation. In addition, smith stated that for information to be successful, it must have relative advantage over ideas or practices that previously exist, compatibility, how is innovation related to adoptors needs, values and experiences? Complexity, what is the level of understanding of the mechanism for applying the innovation into use? Triability is experimentation which show cases evidence, for further commitment to adopt innovation and observability, which is the tangible result provided by innovation. Innovative instructional methods should propagate the cultural values of the society, in order to receive wide acceptance and applicability.

Innovative instructional methods ought to spread from teacher preparatory institutions of universities, colleges of education and polytechnics. In essence, professionally trained teachers are forerunners of innovative methods of teaching social studies. Innovative instructional methods should be problem solving focused and organized to address realistic needs, aspirations and challenges of the society. It should adequately reinforce learning than existing old instructional practices. Seminars, conferences and workshops are channels to equip the target audience - teachers with 
innovative methods. There is need for feed back to assess the potency, weaknesses and limitations of innovative methods through supervision. Innovative method of instruction should be canvassed through the media and academic publications. Innovative method ought to make significant impact in advancing the teaching of social studies, frontiers of knowledge and learning experiences in the school system and beyond.

The further implication of Rogers theory is to understand the processes through which new ideas or technologies can be translated. Teachers must comprehensively adopt innovative instructional methods through continuous professional exposure to resource persons and in-house training among teachers is repeatedly necessary to ensure maximum use of innovative methods. The maximum benefit of innovative instructional method is maximal learning, acquired through learners active involvement, practical ability to construct ideas and create knowledge.

Vygotsky as summarized in Honebein (1996) believe that learning is consummated through social interaction and that learning should be meaningfully presented to learners realistic social experience in terms of contents, skills an tasks. This is to enable the learner construct, develop and create ideas to reinforce effective learning. Teachers use of various innovative methods is to advance the academic progress of learners, furthermore, the linking of innovative teaching method to the real world situation of the learner, makes learning of social studies interesting and permanent. In all, the teacher is a primary distinguished collaborative agent in knowledge diffusion.

\section{Statement of the Problem}

The goal of teaching and learning social studies at the tertiary level of Education is to inculcate desirable behaviours, knowledge, attitudes and skills for individual survival and contribution to national development. Many social studies lecturers do not possess the quality and capability needed for the implementation and achievement of this envisaged goal. Many of them lack requisite facts, knowledge and skills for effective teaching of social studies in schools and this consequently impedes effective actualization of social studies objectives at the tertiary level. Therefore, there is need for social studies lecturers to be acquainted with the requisite knowledge and skills for teaching social studies hence; the relevance and need of CAI teaching strategy in schools. This study however tries to investigate how social studies lecturers are in tune with CAI as an innovative trend of instruction and the relevance of CAI in optimizing the quality of social studies lecturers.

\section{Purpose of the Study}

The main purpose of this study is to determine the relevance of CAI in optimizing the quality of social studies lecturers in Nigerian tertiary institutions.

This study specifically intends to

1. ascertain the extent social studies lecturer possess the requisite knowledge and skills for teaching social studies.

2. determine the awareness of social studies lecturers on the use of CAI for access information.

3. identify the ways CAI helps in boosting and optimizing the quality of social studies lecturers in schools.

\section{Research Questions}

The following research questions guided this study

1. How are social studies lecturers acquainted with the requisite knowledge and skills for teaching social studies?

2. How are social studies lecturers acquainted with CAI as an innovative trend for accessing and imparting information?

3. How will CAI help in optimizing the quality of social studies lecturers in schools?

\section{Design of the Study}

The study adopted descriptive survey research design as the choice was to elicit information from the respondents on the relevance of CAI in optimizing the quality of social studies lecturers in tertiary institutions.

\section{Population of the Study}

The population of the study consisted of all the one hundred and sixty-two (162) Social studies education lecturers in public universities and colleges of education in South-East, Nigeria.

\section{Sample and Sampling Technique}

A sample of 108 social studies lecturers was drawn for the study. This sample size was in line with Cohen, Manion, and Morrison's (2011) criteria for determining sample size from a finite population. Cluster sampling technique was used in drawing the sample. In cluster sampling, the population is divided into distinct units, and every element in the units that are randomly drawn makes up the sample. Thus, since public universities and colleges of education are distinct clusters, 
therefore, using cluster sampling technique, 7 public universities and 5 public colleges of education were randomly drawn from the public tertiary institutions in South-East of Nigeria, for the study. Consequently, all the social studies lecturers in the 12 institutions drawn constituted the sample of the study.

\section{Instrument for Data Collection}

Structured questionnaire titled "Questionnaire on Effectiveness of CAI in Optimizing the Quality of Social Studies Lecturers in Nigerian Tertiary Institutions" was used for data collection. The questionnaire consisted of sections 'A' and 'B'. Section A sought information on the personal data of the respondent while section B sought information on effectiveness of CAI in optimizing the quality of social studies lecturers using sixteen (16) items raised in order to answer the research questions. The instrument was rated based on Likert-type 4 point rating scale of Strongly Agree (SA), Agree (A), Disagree (D) and Strongly Disagree (SD) with the rating scores of 4, 3, 2 and 1 respectively.

\section{Validation of the Instrument}

The structured questionnaire was given to two experts for face validation. One of the experts came from social studies education unit in the department of Social Science Education, Faculty of Education, University of Nigeria, Nsukka and one from the department of Social Studies, College of Education, Oju Benue State. The corrections and suggestions of the experts helped in fine-tuning the final version of the instrument.

\section{Reliability of the Instrument}

Some copies of the questionnaire were trial-tested on 20 social studies education lecturers drawn from University of Port Harcourt, Rivers State, Delta State University, Abraka and Federal College of Education Obudu, Cross River State which were outside the study area, in order to generate data for determining the reliability of the instrument. The internal consistency of the items in the questionnaire was determined using Cronbach Alpha method of establishing the reliability of an instrument. The instrument was found to have an overall reliability co-efficient of 0.78 , which showed that it was highly reliable.

\section{Method of Data Collection}

The researchers carefully administered the instrument directly on the respondents. This approach helped in ensuring hundred percent dissemination and retrieval of the administered questionnaire.

\section{Method of Data Analysis}

Data collated were analyzed using mean and standard deviation. To guide the decision during interpretation, 2.50 was set as the benchmark mean score. By implication, mean scores of 2.50 and above were considered as agreed while mean scores below the benchmark were seen as disagreement.

\section{Results}

Answers to research questions 1,2, and 3 were presented in tables 1, 2 and 3 below.

Research Question 1: How are social studies lecturers acquainted with the requisite knowledge and skills for teaching social studies?

Table 1. Conversancy of social studies lecturers with the requisite knowledge and skills for teaching social studies

\begin{tabular}{|c|c|c|c|c|c|}
\hline $\mathbf{S} / \mathbf{N}$ & ITEMS & $\mathbf{N}$ & $\bar{x}$ & SD & Decision \\
\hline 1 & $\begin{array}{l}\text { Some social studies lecturers are not professionals and } \\
\text { qualified to teach studies. }\end{array}$ & 108 & 2.74 & 0.95 & Agree \\
\hline 2 & $\begin{array}{l}\text { Some social studies lecturers are not aware of the } \\
\text { contemporary issues in social studies. }\end{array}$ & 108 & 3.12 & 0.91 & Agree \\
\hline 3 & $\begin{array}{l}\text { Some social studies lecturers are not acquainted with the } \\
\text { innovative pedagogies for teaching social studies }\end{array}$ & 108 & 3.23 & 0.96 & Agree \\
\hline 4 & $\begin{array}{l}\text { Some social studies lecturers lack the knowledge of many } \\
\text { innovative instructional resources. }\end{array}$ & 108 & 2.79 & 0.72 & Agree \\
\hline 5 & $\begin{array}{l}\text { Some social studies lecturers are not creative and do not have } \\
\text { the skill of improvisation. }\end{array}$ & 108 & 2.12 & 0.74 & Disagree \\
\hline \multirow[t]{2}{*}{6} & $\begin{array}{l}\text { Some social studies lecturers are not aware of the appropriate } \\
\text { pedagogies applicable for teaching each of the social studies } \\
\text { contents. }\end{array}$ & 108 & 2.65 & 1.11 & Agree \\
\hline & Grand Mean & 108 & 2.78 & 0.90 & Agreed \\
\hline
\end{tabular}

Result in Table 1 showed that the mean score of the responses to items 1-4 and item 6 were above the benchmark mean score of 2.50 set for taking decision while the mean score of the responses to item 5 was below the benchmark mean. This 
implies that the respondents agreed that items 1-4 and item 6 were true of social studies lecturers while they disagreed that item 5 is not true of them. The result also showed that the grand mean score of 2.78 with a standard deviation of 0.90 was above the benchmark mean score of 2.50 set for taking decision. Since the grand mean score was above the benchmark mean score of 2.50, this therefore means that the respondents agreed that many social studies lecturers are not acquainted with the requisite knowledge and skills for teaching social studies.

Research Question 2: How are social studies lecturers acquainted with CAI as an innovative trend for accessing information?

Table 2. Conversancy of social studies lecturers with CAI as an innovative method for accessing information

\begin{tabular}{llcccc}
\hline S/N & \multicolumn{1}{c}{ ITEMS } & $\mathbf{N}$ & $\bar{x}$ & SD & DECISION \\
\hline 7 & $\begin{array}{l}\text { Some social studies lecturers are not aware of CAI as a } \\
\text { teaching and information accessible strategy. }\end{array}$ & 2.57 & 1.15 & Agree \\
8 & $\begin{array}{l}\text { Some social studies lecturers are not computer literate. } \\
\text { Some social studies lecturers envisage computer operation as }\end{array}$ & 108 & 3.62 & 0.63 & Agree \\
9 & 2.89 & 0.71 & Agree \\
& $\begin{array}{l}\text { a time consuming event. } \\
\text { Some social studies lecturers believe that computer is for jet }\end{array}$ & 108 & 2.38 & 1.02 & Disagree \\
& $\begin{array}{l}\text { age generation and do not wish for it. } \\
\text { Grand Mean }\end{array}$ & $\mathbf{1 0 8}$ & $\mathbf{2 . 8 7}$ & $\mathbf{0 . 8 9}$ & Agreed \\
\hline
\end{tabular}

Result in Table 2 showed that the mean score of the responses to items 7-9 were above the benchmark mean score of 2.50 set for taking decision while the mean score of the responses to item 10 was below the benchmark mean. This means that the respondents agreed that items 7-9 were true of social studies lecturers while they disagreed that item 10 is not true of them. Moreover, the result also showed that the grand mean score of 2.87 with a standard deviation of 0.89 was above the benchmark mean score of 2.50 set for taking decision. Hence, the respondents agreed that many social studies lecturers are not acquainted with $\mathrm{CAI}$ as an innovative trend for accessing information.

Research Question 3: How will CAI help to optimize the quality of social studies lecturers?

Table 3. Role of CAI in optimizing the quality of social studies lecturers

\begin{tabular}{|c|c|c|c|c|c|}
\hline $\mathbf{S} / \mathbf{N}$ & ITEMS & $\mathbf{N}$ & $\bar{x}$ & SD & DECISION \\
\hline 11 & CAI makes social studies lecturers to be computer literate. & 108 & 3.47 & 0.83 & Agree \\
\hline 12 & $\begin{array}{l}\text { CAI equips social studies lecturers with the knowledge of } \\
\text { innovative methods of teaching social studies. }\end{array}$ & 108 & 3.41 & 0.76 & Agree \\
\hline 13 & $\begin{array}{l}\text { CAI boosts social studies lecturers with the knowledge of the } \\
\text { innovative resources for teaching. }\end{array}$ & 108 & 3.54 & 0.51 & Agree \\
\hline 14 & $\begin{array}{l}\text { CAI gives social studies lecturers access to foreign materials } \\
\text { that help to increase their educational knowledge. }\end{array}$ & 108 & 3.71 & 0.45 & Agree \\
\hline 15 & CAI exposes social studies lecturers to contemporary issues. & 108 & 3.55 & 0.33 & Agree \\
\hline \multirow[t]{2}{*}{16} & $\begin{array}{l}\text { CAI makes social studies lecturers to be internationally } \\
\text { competent. }\end{array}$ & 108 & 3.42 & 0.43 & Agree \\
\hline & Grand Mean & 108 & 3.52 & 0.55 & Agreed \\
\hline
\end{tabular}

Result in Table 3 showed that the mean score of the responses to all the items were above the benchmark mean score of 2.50 set for taking decision. This means the respondents agreed that CAI makes social studies lecturers to be computer literate, equips social studies lecturers with the knowledge of innovative methods of teaching social studies, boosts social studies lecturers' knowledge of the innovative resources for teaching among others. Besides, the grand mean score of 3.52 with a standard deviation of 0.55 was also above the benchmark mean score of 2.50 set for taking decision. This therefore means that, the respondents agreed that CAI helps in optimizing the quality of social studies lecturers.

\section{Summary of the Findings}

1. Many social studies lecturers are not acquainted with the requisite knowledge and skills for teaching social studies.

2. Many social studies lecturers are not acquainted with CAI as an innovative trend for accessing information. 
3. CAI helps in optimizing the quality of social studies lecturers in Nigerian tertiary institutions.

\section{Discussion of Findings}

The findings of this study showed that many social studies lecturers are not acquainted with the requisite knowledge and skills for teaching social studies. This is in line with the observations of Mezieobi and Mezieobi (2002) and Mezieobi (2013) that social studies classrooms are manned largely by people in their traditional disciplines of social sciences (Government, Sociology, Economics, etc) who teach social studies in the light of their disciplinary bias. Continually, they maintained that professionally trained social studies lecturers are hard to come by. Against this background, Okam (2012) reiterates that only professionally trained teachers and lecturers of social studies (who are acquainted with the knowledge of both national and world contemporary issues) can achieve instructional effectiveness in the delivery of classroom instructions. Hence, Mezieobi and Mezieobi (2012) and Mezieobi, Ojobo, Onyeanusi and Sampson (2013) call for recruitment of professionally trained social studies lecturers in Nigerian tertiary institutions.

This study also revealed that many social studies lecturers are not acquainted with CAI as an innovative trend for accessing information. Hence, they rely on conventional methods of teaching which make for learners' passivity instead of creativity. This aligns with the research findings of Linda (2000), Nwaubani (2008) and Okam (2012) which indicated prominent teachers' reliance on traditional methods in teaching social studies. Corroboratively, Egbogu, Asogwa and Chukwuemeka (2007) in Mezieobi (2012) through their researches revealed the low extent of the use of (innovative) instructional resources in teaching social studies. In consonance, Mezieobi (2004) in a study at Abia found the slim use of innovative instructional resources and diverse pedagogies in teaching social studies in schools.

The reasons for the poor acquaintance with CAI as an innovative trend have also been revealed by some studies. For instance, Nworgu (2007) and Usman (2007) in their separate studies indicated that most (social studies) teachers and lecturers are not information and communication technology compliant. A study by Mezieobi and Mezieobi (2008) proved that social studies lecturers are not sufficiently trained in the utilization of information and communication technologies which computer device is inclusive. Consequently, the use of innovative teaching methods and resources are least contemplated let alone utilized (Mezieobi \& Mezieobi, 2012). Mezieobi (2010) and Mbakwem and Ibeh (2012) had reiterated that ICT (computer) materials are valuable materials that are quite paramount for teachers and lecturers in our schools and for that warned that teachers should be trained in the use of ICT as new devices for boosting their professional colleagues, learning new ideas, new methods and be acquainted with new discoveries that are germane for teaching and learning social studies in schools.

Furthermore, study revealed that CAI helps in optimizing the quality of social studies lecturers in Nigerian tertiary institutions. This is in line with the view of Akinola (2012) that CAI helps social studies lecturers to cross fertilize ideas on current issues in social studies curriculum. Gushen (1998) in Akinola (2012) also remarked that CAI gives significant improvement in the quality of lecturers' researches and teachings. In corroboration, Yusuf (2005) noted that CAI helps to change teachers' professional development through constant update of their knowledge on the use of computers in content areas. Based on these observations, Gele (2012) warned that teachers should be well prepared to use new teaching methods and materials with the new ICT tools for learning.

\section{Educational Implications}

The educational implications of this study include the followings:

1. Social studies lecturers need to be acquainted with the requisite professional knowledge and skills for teaching social studies in Nigerian tertiary institutions.

2. CAI enables social studies lecturers to access innovative teaching pedagogies and materials that make for effective teaching and learning of social studies in schools.

3. Social studies lecturers ought to make themselves to be computer competent for effective application of CAI in their teaching-learning process.

4. Social studies lecturers should effectively apply diverse innovative teaching methods and resources for enhancement of learning.

\section{Conclusion}

Computer-Aided-Instruction (CAI) is an innovative teaching method that maximizes the professional capabilities of social studies lecturers in Nigerian tertiary institutions. It is very powerful in optimizing the quality of social studies lecturers in schools. As an innovative method that is germane for boosting the quality of social studies lecturers in schools, there is need for CAI learning packages to be incorporated into teacher preparatory programmes to help equip the practicing and would-be lecturers with the competencies and capabilities for effective teaching of social studies in schools especially in Nigerian tertiary institutions. 


\section{Recommendations}

Based on the findings of this study, the following recommendations were made:

1. Professional and qualified social studies lecturers should be recruited to teach social studies in Nigerian tertiary institutions.

2. Social studies lecturers should try to be computer and ICT compliant.

3. School authorities and governments should endeavour to provide ICT laboratory room to enable lecturers have access to computers and be able to adopt CAI for optimization of their lecturers' knowledge and skills.

4. ICT seminars, workshops and conferences should be organized in schools to help orient lecturers on the benefits of CAI mode of instructions.

5. Social studies lecturers should always try to apply innovative teaching methods and resources in their classroom instructions in order to maximize learning.

\section{References}

Akinlaye, F. A. (2003). Fundamentals of Social Studies Curriculum. Lagos: Pumark.

Akinola, D. B. (2012). The Relevance of Information and Communication Technologies to Social Studies Education Curriculum in Nigeria. Nigerian Journal of Social Studies, 15(2), 133-135.

Enem, F. O. (2005). The Importance of Implementation of Social Studies Curriculum at Junior Secondary School level. Social Studies Quarterly, 1(1), 48-56.

Ezekoka, G. K. (2006). Evaluation of Secondary School Teachers' use of Information and Communication Technology (ICT) for Curriculum Implementation. A Paper presented at the $5^{\text {th }}$ International Conference of National Association on Women's Academics (NAWACS) at Imo State University, Owerri.

Federal Republic of Nigeria. (2004). National Policy on Education. Abuja: NERDC.

Gele, S. A. M. (2012). Repositioning Social Studies Education for Sustainable Democratic Challenges in Nigeria. Nigerian Journal of Social Studies, 15(2), 146-159.

Honebein, B. (1996). Psychology of Learning: Research and Theory. New York: Ronald press.

Linda, A. C. (2000). Teacher Quality and Students' Achievement: A Review of State Policy Evidence. In Glass (ed) Electronic Journal in Educational Policy Analysis Archives, 8(1), 1-26.

Mbakwem, J. N., \& Ibeh, A. I. (2012). Assessment of Information and Communication Technology (ICT) knowledge of Social Studies and Government Teachers in Ebonyi State. Nigerian Journal of Social Studies, 15(2), 174-186.

Mezieobi, D. I. (2010). Repositioning Social Studies Education for Sustainable Lifelong Education in Nigerian Universities. (In print).

Mezieobi, D. I. (2012). Teaching Practice in Social Studies Education in Nigeria. Owerri: GABTONY.

Mezieobi, D. I. Akpochafo, W. P., \& Mezieobi, S. A. (2010). A Review of Social Studies Education Implementation in Secondary Schools. Journal of curriculum Theorists and Educational Technologists, 1(1), 126-143.

Mezieobi, D. I., \& Mezieobi, S. A. (2008). Teaching Contemporary Issues in Social Studies Education. In Review of Education, 16(2), 125-131.

Mezieobi, D. I., Ogaugwu, L. N., Ossai, J. N., \& Young, S. C. (2012). Agenda for Transformative Implementation of Social Studies Curriculum in Nigerian University. Paper presented at the $9^{\text {th }}$ biennial Conference of World council for Curriculum and Instruction (WCCI) Nigerian Chapter. Held at the University of Nigeria, Nsukka. October 17-20.

Mezieobi, D. I., Ojobo, H. I., Oneanusi, O. C., \& Sampson, M. (2013). Revolution in Social Studies Teacher Preparation: A Critical Agenda for Effective Method Translation in the Classrooms. Rivers Journal of Social Studies, 8(6), 40-54.

Mezieobi, D. I., Ossai, J. N., Onyeanusi, O. C., \& Egharevba, J. (2012). Vision 20:2020 and Implication for the Effective Implementation of social Studies Curriculum in Nigerian Junior Secondary Schools. Nigerian Journal of Social Studies, 15(2), 202-220.

Mezieobi, K. A. (2002). Evaluation of the Implementation of the Junior Secondary School Social Studies Curriculum in Abia State. An Unpublished Ph.D Dissertation. Delta State University Abraka, Nigeria. 
Mezieobi, K. A. (2004). Social Studies Teaching Methods and Techniques. In G. W. Joof \& H.C. Amadi (Eds) Social Studies in Schools. Onitsha: Outrite.

Mezieobi, K. A. (2013). Social Studies Curriculum. Owerri: AcadaPeak.

Mezieobi, K. A., \& Mezieobi, K. C. (2012). A Hand Book of Social Studies Competencies. Owerri: Priscilla Omama.

Mezieobi, K. A., \& Mezieobi, S. A. (2012). Needed Change in Social Studies Curriculum in Nigeria: The Critical Areas. Journal of Social Studies, 15(1), 132-144.

Mezieobi, K. A., Fubara, V. R., \& Mezieobi, S. A. (2008). Social Studies in Nigeria: Teaching Method, Instructional Materials and Resources. Owerri: AcadaPeak.

Njoku, C. (2012). Collaborative Learning: An Innovative Teaching Method for Social Studies Instruction. Nigerian Journal of Social Studies, 15(1), 22-35.

Nwaubani, O. O. (2008). Maintaining Standard in Social Studies: Teacher Preparation, issues, Challenges and Policy Implication for Education Instructional Delivery at the various UBE levels in Nigeria. Journal of Curriculum Studies. Special Edition.

Nwaubani, O. O. (2010). Enhancing Value Education Potentials of Primary School Pupils in Nigeria through Social Studies: Strategies and Implications for Integrated national Development. In E. Osakwe (ed) Social Studies and Integrated National Development in Nigeria. Ibadan: Kraft Books.

Nworgu, B. G. (2007). The indispensability of ICT in Educational Research. In D.N. Eze \& N. Onyegegbu (eds) Information and Communication Technology in the Service of Education Enugu: Timex.

Nwosu, S. E. (2002). Fundamentals of Computer Education and Educational Technology. Enugu: Cedartop.

Odigwe, E. E. (2007). Lack of Skilled Teachers and teacher Equipment as factors militating against mathematics Education in Nigeria. Journal of Education for Professional Growth, 3(1), 39-43.

Offorma, G. C. (2006). Curriculum Issues in the $21^{\text {st }}$ Century. Key Note Address presented at the Second Annual Conference of Curriculum Organization of Nigeria, Calabar Chapter at Cross River State University of Technology.

Okam, C. C. (2012). Needed Paradigm Shift for Repositioning Social Studies Education to Meet Vision 20-2020 challenges in Nigeria. Nigerian Journal of Social Studies, 15(2), 15-41.

Okolo, A. N., \& Nweze, V. I. (2010). Quality Teacher Preparation: A key Factor for the Achievement of Vision 20:2020 in Nigeria. In U. Eze \& N. Onyegegbu (eds) Teacher Preparation and Vision 20:2020 in Nigeria. Enugu: Timex.

Okpoebo, C. C. (2018). Teachers awareness and use of Innovative Teaching Approaches in Teaching Government in senior secondary schools in Nasarawa Education zone, Nasarawa state, Nigeria. unpublished M.Ed project, University of Nigeria, Nsukka.

Smith, K. (2009). Innovative in Public Education: Problems and Opportunities. New schools venture Fund Carnegie corporation. New York: www.newschools.org/files/innovation.

Usman, K. O. (2007). Information and Communication Technology (ICT) Competencies for the Implementation of Mathematics Curriculum. In D.N. Eze \& N. Onyegegbu (eds) Information and Communication Technology in the Service of Education. Enugu: Timex.

Yusuf, M. O. (2005). Meridian: An Middle School Computer Technologies Journal, a Service of NC State University, Releigh, NC, 8(2), 1.

\section{Copyrights}

Copyright for this article is retained by the author(s), with first publication rights granted to the journal.

This is an open-access article distributed under the terms and conditions of the Creative Commons Attribution license (http://creativecommons.org/licenses/by/4.0/). 